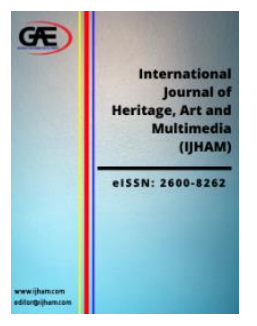

\author{
International Journal of Heritage, Art and \\ Multimedia (IJHAM) \\ Journal Website: http://ijham.com/ \\ eISSN: 2600-8262
}

\title{
APPENDING ROLES OF THAI LANNA TEMPLES FOR SUSTAINABLE COMMUNITIES: A CASE STUDY OF WAT PHUMIN, NAN PROVINCE
}

\author{
Tawipas Pichaichanarong ${ }^{1}$, Veerawat Sirivesmas $^{2}$, Rueanglada Punyalikhit ${ }^{3}$
}

1 Suan Sunandha International School of Art. Suan Sunandha Rajabhat University, Nakhon Pathom Campus, Thailand.

Email: tawipas.pi@ssru.ac.th

2 Silpakorn University, Bangkok, Thailand.

Email: veerawatsi@gmail.com

3 Silpakorn University, Bangkok, Thailand.

Email: rueanglada.pun@gmail.com

\section{Article Info: \\ Article history: \\ Received date:26.11.2019 \\ Revised date: 22.01.2020 \\ Accepted date: 25.01 .2020 \\ Published date: 10.03.2020}

\section{To cite this document:}

Pichaichanarong, T., Sirivesmas, V., \& Punyalikhit, R. (2020). Appending Roles of Thai Lanna Temples for Sustainable Communities: A Case Study of Wat Phumin, Nan Province. International Journal of Heritage, Art and Multimedia, 3 (8), 01-11.

DOI: $10.35631 /$ IJHAM.38001.

\begin{abstract}
:
Temples have been important in Thai society for over 700 years. When the Sukhothai Kingdom (1238 -1438 AD) was the capital city of Thailand. The great King Ramkamhang had been accepted Theravada Buddhism to be the strongest religion in the land. Later Lanna kingdom (1296 - 1558 AD) was founded in the mid-13th century by King Mangrai. Indeed, King Ramkamhang was friends with King Mangrai, and King Ngam Muang of Phayao Kingdom (1094-1338 AD), it is possible Theravada Buddhism had been introduced to the kingdoms during the reigns of these three Kings. Indeed, the Lanna Kingdom has accepted Theravada Buddhism to be their religion. Until 1894, Lanna Kingdom combined with Siam Kingdom which is the Rattanakosin period (1782 AD - present). Throughout history, temples have become an essential part of Lanna and Thais' lives. At present, some Thai Lanna temples are not only functions for performing religious rites, but also, they become central for Lanna and Thai communities. Temple ("Wat" in Thai) is a sacred architecture. Moreover, there are ideas to decorate inside temples with arts. Wattana Boonjub (2009) points out that Mural painting is used to teach (Lanna and) Thai people in the past. For example, Wat Phumin, Nan province. With beautiful Lanna architecture and exquisite Lanna mural paintings, these are intangible heritages. These unique characteristics have invited lots of people to visit this temple for years. Therefore, Wat Phumin became a tourist attraction that creates revenue for its community. Johan Galtung (1980) gave the definition for "Self-Reliance", is the strategy for development to be financial independence. With collaboration from the community, it becomes a sustainable community. For Methodology, quantitative and qualitative methods were used by collecting the data from tourists who have been visited Wat Phumin, Nan province. The data then were analyzed using mean,
\end{abstract} Copyright $\odot$ GLOBAL ACADEMIC EXCELLENCE (M) SDN BHD - All rights reserved 
descriptive statistics, and qualitative data. This study concludes that Wat Phumin, Nan province has created a sustainable community for its community.

Keywords:

Thai Lanna Temples, Wat Phumin, Self-Reliance, Stakeholders, SustainableCommunity

\section{Introduction}

\section{Thai Lanna Temples}

Temples have been important in Thai society for over 700 years. When the Sukhothai Kingdom (1238 -1438 AD) was the capital city of Thailand, King Ramkamhang accepted Theravada Buddhism to be the religion of the kingdom. Accordingly, Lanna Kingdom was founded in 1296 AD, Theravada Buddhism also accepted as the religion of Lanna kingdom. Historically, Lanna Kingdom was united with Siam Kingdom in 1894, which is Rattanakosin period (1782 AD - present). Later, Siam Kingdom was renamed to be the Kingdom of Thailand in 1939. As a result, Lanna temples are in the area of Lanna Kingdom in the northern region of Thailand, can called "Thai Lanna temples" interchangebly.

\section{Literature Review}

\section{Wat Phumin, Nan Province}

Nan is located in the northern part of Thailand, known as "the Kingdom of Lanna." All of arts in Nan considers as Lanna Art, which represents the northern part of Thailand, known as "the Kingdom of Lanna." As the matter of fact, this study will focus on the government's region that represents "the Kingdom of Lanna," consisting of 8 provinces (Chiang Mai, Chiang Rai,Lampang, Lamphun, Phayao, Phrae, Mae Hong Son, and Nan).

Wat Phumin is different from the rest of the Wats in Thailand. The ordination and assembly halls are put together in one building which is contructed on a cross-shaped plan. The building has square center and has four equal projections with similar projections at cardinal points. Poignant Naga balustrades are made along the steps leading to the doors, which is the common of the Buddhist hall of the north direction. Wat Phumin was built in Ayutthaya period (1351 1767 AD). At that time, Nan was conquered by Burma, so its architecture style reflects very much like Burmese style of temple, as figure 1.

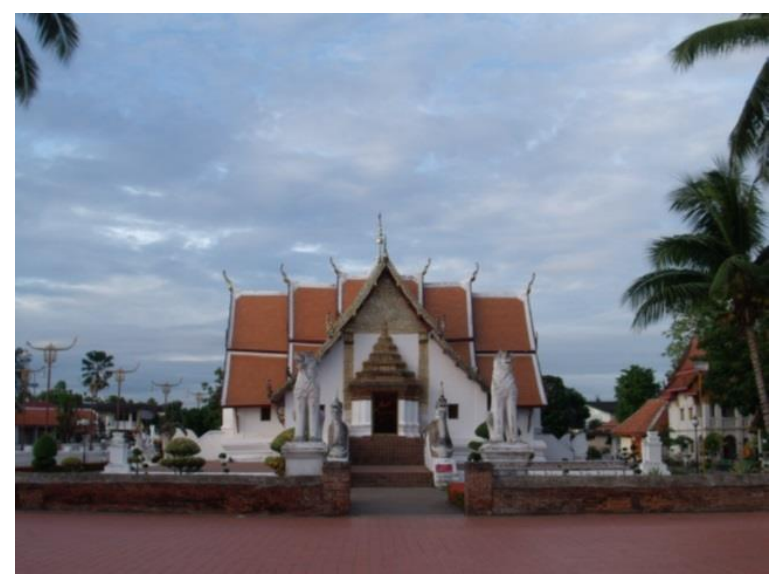

Source: Tawipas Pichaichanarong

Figure 1: Wat Phumin, Nan province 
At that time the majority of Thai population were illiterate, only Buddhist monks were educated in the temple, which to study the ancient scriptural language "Pali". As a result, murals were used to represent the teachings of Buddha because they were easy to understand and remember. At the present, some Thai temples are not only function for performing religious rites, but also they become a central for Thai communities as Wat Phumin, Nan province in this study as Figure 2..With beautiful architecture and exquisite mural paintings, these are intangible heritages. These unique characteristics has invited lots of people to visit this temple for years.

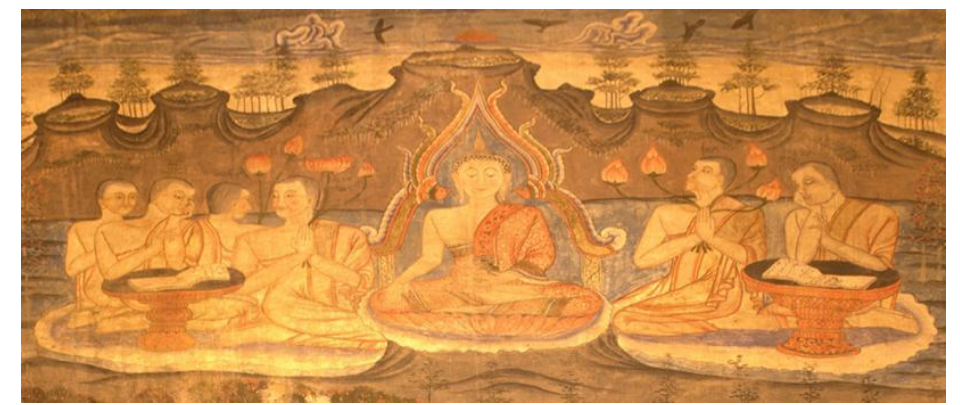

Figure 2: Mural painting at Wat Phumin, Nan province

Source: Tawipas Pichaichanarong

\section{Self-Reliance}

Frederic et al. (1991) points out that Self- reliance does not mean that a community is isolated from the mainstream economy. Self-reliance means the regeneration of the community through community-controlled of its own resources (natural, human, and cultural). This includes the determination of the manner in which resources relate to both the community's internal economy and the mainstream economy (p.27). C.C. Fonchingong \& L.N. Fonjong (2002) suggested that self- reliance should find a balance between the basic need of local people and the contribution from the local economy.

In addition, Johan Galtung (1980) gave the definition for "Self-Reliance", is the strategy for development to be financial independence. With collaboration from community, it becomes sustainable community.

As a result, self-reliance means to control community's resources with reasonable solutions, and diversified its limited resources with full potential.

\section{Stakeholders}

According to original of the word "Stakeholder" first came into existence in 1708 (Ramirez, $1999 ; 101)$. The root causes of stakeholder analysis arose from the management of natural resources. When some people have exploited the environment and the natural resources became depleted. The affected people reacted to the situation. They called the authorities to resolve the situation between the beneficiaries and the affected people. When conflicts caused criticisms and battles in various forms and levels. It became problems and the problems expanded. Consequently, the knowledge to tackle the problems is shared by academics from the university and World Bank. When the concept of stakeholder analysis is used in the organization's communication management, it reflects that there is a stakeholder organization. It became clear that organizations must communicate with multiple individuals, such as outside organizations, communities, mass media, customers, government agencies, or third parties. Stakeholders of 
the organization are divided into two main groups, the stakeholders within the organization and the stakeholders outside the organization (Pirote Wilainuch, 2008, p.52). On the other hand, there layers of stakeholders, which are core, primary, and secondary.

\section{Intangible Heritages}

UNESCO has been used the term "Intangible heritage" in order to describing cultural heritage which does not physical objects, but it contains traditions or living expressions inherited from generation to generation. For example, oral traditions, performing arts, rituals, etc. There are conditions to define what "Intangible heritage" from UNESCO is; which are; traditional, inclusive, heritage, representative, and community based.

\section{Traditional}

Intangible heritage does not represent existing traditions from the past, but it depicts contemporary traditions from all culture.

\section{Inclusive}

Intangible heritage is important to certain group or people with same backgrounds.

\section{Heritage}

Intangible heritage is the valuable assets that pass on from ancestor to descendant.

\section{Representative}

Intangible heritage has specific set of knowledge to transfer to other generation or communities.

\section{Community-based}

Intangible heritage represents the knowledge from the community (Retrieved on September $25^{\text {th }}, 2018$ ).

\section{Sustainable Community}

Sustainability implies different solutions for different places; it is qualified by its context. (Van der Ryn and Calthorpe, 1991) explains Sustainability implies balance and permanence. For example, a balance between people living in a community; a balance between renewable resources that available for local consumption; a balance between maintaining the natural environment in good health and the needs of the human community which lives within it (p.58). As a result, a sustainable community consists of various factors within community, and has to be balance as figure 3 . 

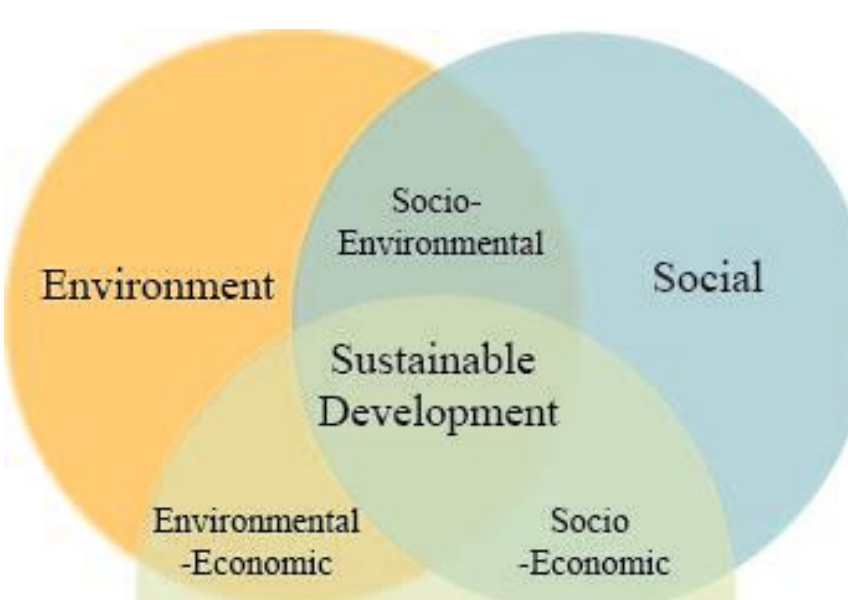

Economic

\section{Figure 3: Sustainable Development Model}

Source: The International Institute for Sustainable Development (IISD)

\section{Hypothesis}

H - 1 Wat Phumin, Nan province has created sustainable development for its community

To Test $\mathbf{H} \mathbf{- 1}$ this study used difference approach to find the hypothesis.

\section{Theories Integrated}

The framework used was the process-context approach to demographic behavior (Willekens, 1990; De Brujin, 1999). Leo J.G. and Van Wissen (1999) added the process-context approach in demographic research has got momentum in recent years. This development is emulated not only in theoretical developments but also in an alteration in the methodological at the center of the field.

\section{Methodology}

Questionnaires were used by collecting the data from the total of 411 Thai and foreign tourists who have been visited Wat Phumin, Nan province (Pichaichanarong T., 2016). At the sometime, qualitative method was used by collecting the data from tourists who have been visited Wat Phumin, Nan province. The data then were analyzed using mean, descriptive statistics, and qualitative data. In addition, qualitative data were arising from questionnaire and in-depth interview as table 1 and table 2 .

\begin{tabular}{|c|c|c|}
\hline \multicolumn{3}{|c|}{ Table 1 Gender Descriptive Statistics } \\
\hline Gender & Numbers & Percentages \\
\hline Male & 161 & 39.2 \\
\hline Female & 250 & 60.8 \\
\hline Total & 411 & 100 \\
\hline
\end{tabular}




\begin{tabular}{|c|c|c|c|}
\hline \multicolumn{5}{|c}{ Table 2 } & Age Descriptive Statistics \\
\hline Age Percent & Frequency & Valid Percent & Cumulative Percent \\
\hline $0-10$ & 4 & 1.0 & 1.0 \\
\hline $11-17$ & 15 & 3.6 & 4.6 \\
\hline $18-25$ & 195 & 47.4 & 52.1 \\
\hline $26-35$ & 68 & 16.5 & 68.6 \\
\hline $36-45$ & 73 & 17.8 & 86.4 \\
\hline $46-55$ & 28 & 6.8 & 93.2 \\
\hline$>55$ & 28 & 6.8 & 100 \\
\hline Total & 411 & 100 & 100 \\
\hline
\end{tabular}

For the questionnaire, there are 411 representative samples by random sampling. There are 161 male $(39.2 \%)$ and 250 females $(60.8 \%)$. For the status issue, there are 12 persons $(2.9 \%)$ for young tourists, 388 persons $(94.4 \%)$ for Thai tourists, 11 persons $(2.7 \%)$ for foreign tourists. For the education level, there are 22 persons (54\%) have primary school education, 48 persons (11.7\%) have secondary school education, 15 persons (3.6\%) have vacation school education, 249 persons $(3.6 \%)$ have bachelor degree education, 70 persons $(17 \%)$ have master degree education, and 7 persons $(1.7 \%)$ have Ph.D. degree education. Mean for frequency from different age groups is 58.7 .

\section{Participants}

To recruit one individual for five selected Stakeholder groups both Primary and Secondary Stakeholders.

\section{Interviews}

The study was approved by Graduate School from Silpakorn University. The researcher Obtained written permission to conduct an interview from study participants before each subsequent interview. The researcher conducted in-depth interviews at four days with the stakeholders. The researcher asked The stakeholders to discuss about the main issues on the hypothesis.

\section{Fieldwork}

In order to learn about personal experiences about Sustainable community, the research the conducted in-depth

\begin{tabular}{|l|l|}
\hline \multicolumn{1}{|c|}{$\begin{array}{c}\text { Table 3 Interviewing with selected Stakeholders both primary and secondary for } \\
\text { Wat Phumin, Nan province }\end{array}$} & \multicolumn{1}{c|}{ List of Stakeholders } \\
\hline \multicolumn{1}{|c|}{ Stakeholders } & $\begin{array}{l}\text { - Buddhist abbot and monks at } \\
\text { Wat Phumin, Nan province } \\
\text { - Wat Phumin - Tali Community } \\
\cdot \text { Tourist }\end{array}$ \\
\hline 2.Secondary Stakeholders & $\begin{array}{l}\text { - Nan Municipality } \\
\text { Office of Ministry of Tourism and } \\
\text { Sports, Nan Province }\end{array}$ \\
\hline
\end{tabular}




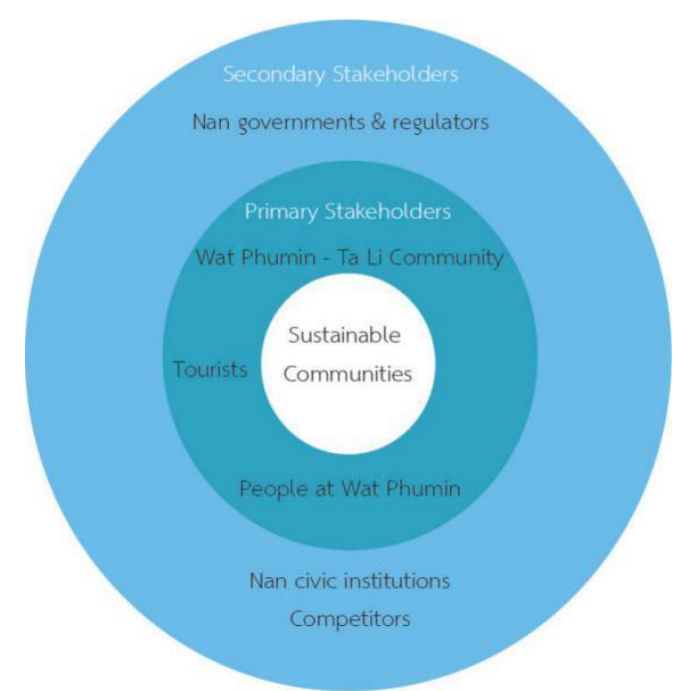

Figure 4: Mapping Stakeholders

Source: Tawipas Pichaichanarong

\section{Analysis}

From the random answers from in-depth interviews with individuals who were selected from Primary and Secondary Stakeholders to analyze the hypothesis: Primary Stakeholders (figure 4.) Most of the tourists (18- 25 years old) came to Wat Phumin only to see are renowned painting "Poo Marn Yar Marn"(Whispering of Love), it was famous internationally (Pichaichanarong T., 2017).

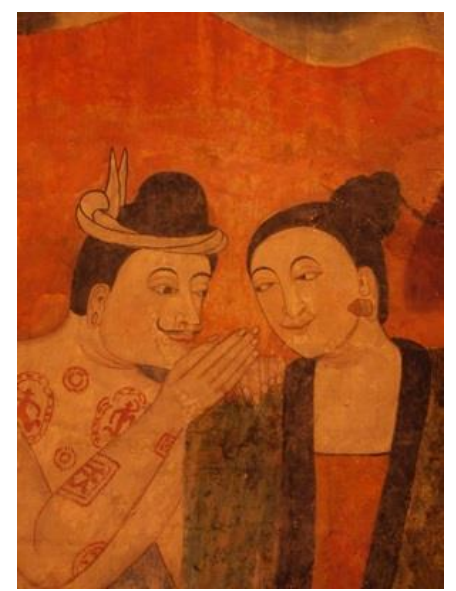

Figure 5: Poo Marn Yar Marn ('Whispering of Love')

Source: Tawipas Pichaichanarong

Nan Municipality has encouraged have local street foods and various of shops on every Friday

- Sunday on the street next to Wat Phumin, Nan Province as figure 6. 


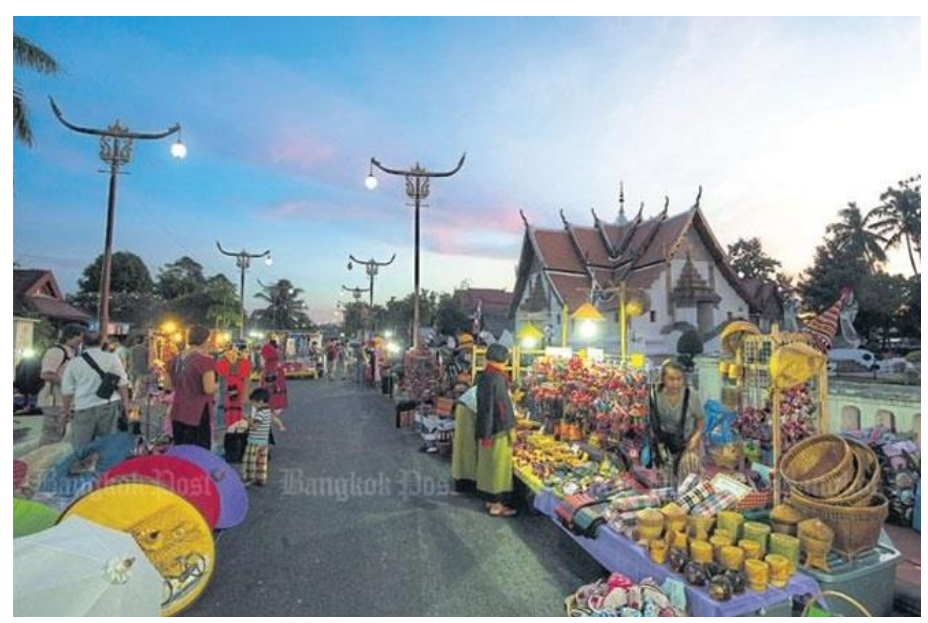

Figure 6: Walking street, Nan province

Source: Bangkok Post

From a model of sustainable development, Wat Phumin, Nan province answered all three criteria to be a sustainable community as figure 7 , figure 8 , and figure 9 .

For Environment: Wat Phumin is an intangible heritage. With beautiful architecture and intriguing mural painting inside the temple. Wat Phumin has reframed the definition of Thai temples in difference meaning in the modern time.

For Social: Wat Phumin's stakeholders had helped each other to engage the activities around Wat Phumin in creative ways.

For Economic: Wat Phumin's value became the intangible assets for its community.

Thus, Wat Phumin was also created jobs for its community.

Therefore, Wat Phumin, Nan province has created sustainable development for its community.

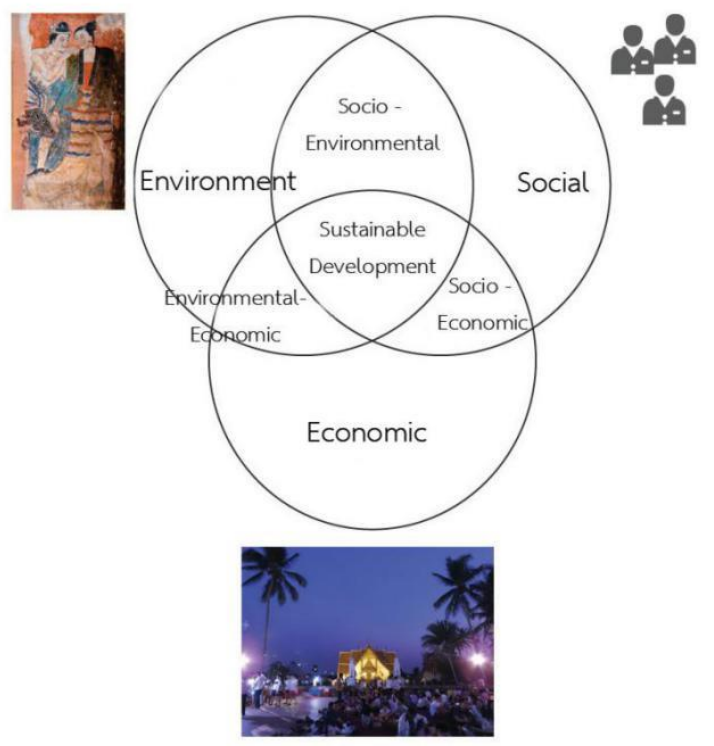

Figure 7: Model of Sustainable Development on Watphumin, Nan Province

Source: Tawipas Pichaichanarong 


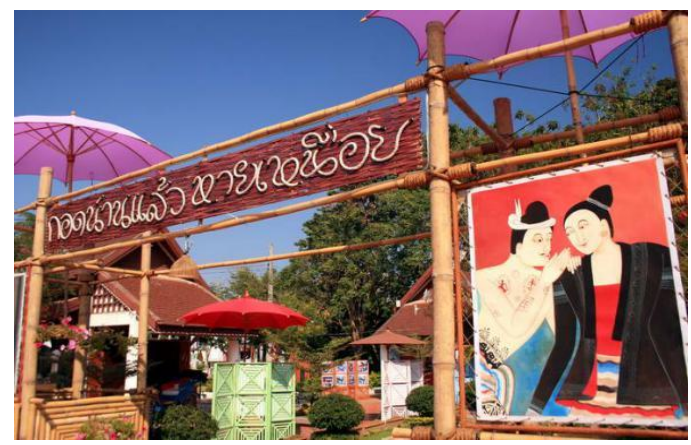

Figure 8: Example of Sustainable Community for Economic

Source: http://oknation.nationtv.tv/blog/key/2011/02/14/entry-2

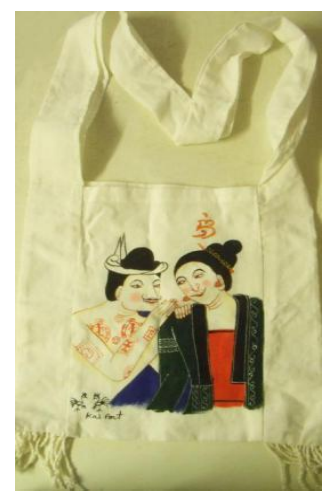

Figure 9: Example of Sustainable Community for Economic

Source: Koi Art (2019)

\section{Quantitative vs. Qualitative}

In this research, the researcher used both Quantitative and Qualitative to test hypothesis. Due to the nature of their differences, Christian Rohrer (2014) explained the events; it is dealing with how many and how much types of questions. On the other hand, qualitative methods are more suitable for answering questions about why or how to fix a problem. The following figure (Figure 10.) shows how two methods have influenced the types of questions that can be inquired.

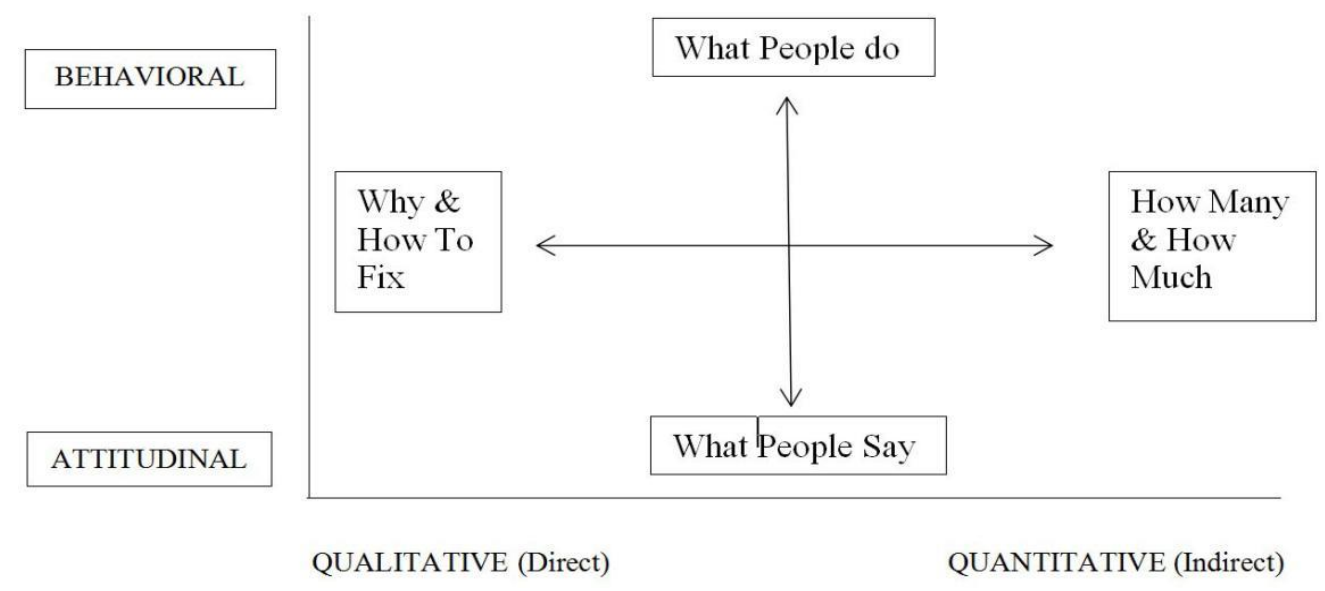

Source: Christian Rohrer (2014)

Figure 10: Quantitative vs. Qualitative

Copyright $\odot$ GLOBAL ACADEMIC EXCELLENCE (M) SDN BHD - All rights reserved 


\section{Discussion}

The results support the mentioned hypothesis. This study concludes from in-depth interview from both Primary and Secondary Stakeholders with in-depth interview from Thai and Foreign tourists, that Wat Phumin, Nan province has created sustainable community for its community. According to more research supports Thailand's tourism, Mingsarn Kaosa-ard (2002) found that the composition of tourism consists of three characteristics; there are 1. The product is composed of natural resources which are public goods: beaches, waterfalls, mountain, and the general environment. 2. Safety and infrastructure are also important elements of the product. 3. A nation's people and their culture, and visitors' access to both are important components of any tourism product or package. Indeed, Wat Phumin and its mural paintings are cultural heritages for Nan province. As times went by for many centuries, Nan's cultural heritages become one of important factors for Nan's revenues. In addition, the results report that our participants have established a statement on Wat Phumin, Nan province as a sustainable community. The statement has reframed the function for Thai temples into a model for sustainable development in Thai modern era.

\section{Acknowledgement}

The authors are truly appreciated The 3th International Conference on Media Studies (ICMS 2019) to accept this paper. In addition, the authors would like to thank Suan Sunandha International School of Art. Suan Sunandha Rajabhat University, Nakhon Pathom Campus, Thailand and Ph.D. Program in Design Arts International Program, Silpakorn University, and Bangkok, Thailand for their supports. Moreover, the authors wish to thank the authors' families who are truly the source of courage to continue our journey in academic arena.

\section{References}

Boonjub, W. (2009). The study of Thai traditional architecture as a resource for contemporary building design in Thailand. Bangkok: Graduate School, Silpakorn University.

De Bruijn, B.J. (1999). Foundations of Demographic Theory. Choice, process, context. Amsterdam: Thela Publishers

Fonchingong, C. C., \& Fonjong, L. N. (2002). The concept of self-reliance in community development initiatives in the Cameroon grassfields. South Africa: GeoJournal, 57(1), 3-13.

Galtung, J., O'Brian, P., \& Preiswerk, R. (1980). Self-Reliance: a strategy for development. London: Bogle-L'Ouverture Publications.

Kaosa-ard, M. (2016). Development and Management of Tourism Products: The Thai Experience. Chiang Mai: Social Research Institute, Chiang Mai University.

Pichaichanarong, T. (2016). Visual Methods in Social Research on Lanna Mural Painting: A Case Study of Wat Phumin, Nan Province. International Journal of Creative and Arts Studies, 3(2), 25-33. https://doi.org/10.24821/ijcas.v3i2.1842

Pichaichanarong, T. (2017). Visual mixing research methods on Lanna mural paintings: A Case Study of Wat Phumin, Nan province. Humanities, Arts and Social Sciences Studies (HASSS), 17(3), 193-210. https://doi.org/10.24821/ijcas.v3i2.1842

Ramı'rez, R. (1999). Stakeholder analysis and conflict management. In Cultivating peace: Conflict And collaboration in natural resource management, ed. D. Buckles.

Ottawa,Canada: International Development Research Centre. (2018, July 10). Retrieved From https://idl-bnc-idrc.dspacedirect.org/bitstream/handle/10625/29303/IDL29303.pdf? sequence $=1=$. 
Rohrer, C. (2014). When to Use Which User Experience Research Methods. [online] Nngroup.com. Available at: https://www.nngroup.com/articles/which-ux-researchmethods/ [Accessed 31 March. 2019].

Sargent, F. O., Lusk, P., Rivera, J., \& Varela, M. (1991). Rural environmental planning for sustainable communities.Washington, DC: Island Press.

Van der Ryn, S., \& Calthorpe, P. (1991). Sustainable Communities - A New Design Synthesis for Cities,Suburbs and Towns. San Francisco: Sierra Club Books.

What is Intangible Cultural Heritage? - intangible heritage - Culture Sector - UNESCO. (2018, September 25). Retrieved from https://ich.unesco.org/en/what-is-intangible-heritage00003.

Wilainuch, P. (2014). Organizational Communication Management: Communication with Stakeholders. Bangkok: Chulalongkorn University Press.

Willekens,F.J. (1990). Beweging in de Demografie [Movement in demography]. Inaugural lecture, Rijksuniversiteit Groningen (in Dutch)

Wissen, V., J.G, L., \& Dykstra, P. (1999). Population Issues: An Interdisciplinary Focus. New York: Kluwer Academic/Plenum Publishers. 